
and Aromatic Plants

An International Journal

ISSN: 2619-9645 | e-ISSN: 2667-5722

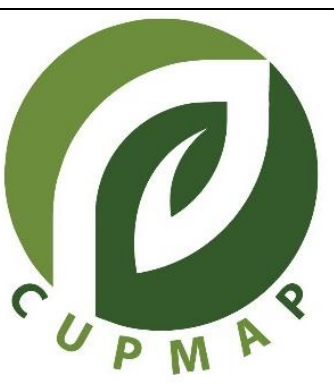

\title{
Economically Important Sage Species from Turkey: Salvia fruticosa Mill. and $S$. aramiensis Rech fil.
}

\author{
Nadire Pelin BAHADIRLI* ${ }^{*}$ iD \\ Department of Field Crops, Faculty of Agriculture, University of Hatay Mustafa Kemal, 31060, Hatay-Turkey \\ *Corresponding author : pelinbahadirli@gmail.com
}

https://doi.org/10.38093/cupmap.736482

Received : 02/05/2020 Accepted : 27/06/2020

\begin{abstract}
Medicinal and aromatic plants have an increasing demand but this demand requires qualified material. Most of the products still obtained from nature. The mint family (Lamiaceae) contains more than 7000 species and the largest genera of the family are Salvia, Scuttellaria, Stachys, Plectranthus, Hyptis, Teucrium, Vitex, Thymus and Nepeta. The member of the family has a value through their secondary metabolites. Essential oils are the most important secondary metabolite in many of the species in the family. The genus Salvia consists of 1000 species which 107 of the taxa represented in Turkey. This review focuses on two Salvia species from natural flora of Turkey: Salvia fruticosa and Salvia aramiensis. Salvia fruticosa Mill. with wide distribution is a very important commodity with medicinal and aromatic properties. Besides that, S. aramiensis Rech. fil. occurs in a restricted area in Turkey but depending on low camphor and thujone content has a great potential to be part in trade. The importance of two species were estimated and future approaches were discussed. Especially the botany, distribution, domestication, spread, cultivation, previous studies on agricultural aspects, biological properties, breeding, molecular characterization of the species were discussed.
\end{abstract}

Key Words: Botany, Essential oil, Salvia, Sage

(C) CUPMAP. All rights reserved.

\section{Introduction}

Plants have been used to cure diseases, spice in foods and bio stimulating material since ancient times. Lamiaceae family contains approximately 236 genera, and one of the most important genus is Salvia. The genus Salvia includes almost 1000 species has a great diversity and wide distributions from Far East, through Europe and across to the New World (Kintzios, 2000). Salvia genus represented by 100 species, 7 varieties in Turkey (Kusaksiz, 2019). There are many species exist in the genus that valuable in cosmetic, food, pharmaceutical industries
(Carović-Stanko et al., 2016). Many of the family members contain secondary metabolites, especially essential oils that efficient as antioxidants, antimicrobial, antiAlzheimer, anticancer, even insecticidal (Pavlidou et al., 2004; Senel et al., 2010; Exarchou et al., 2015; Sarrou et al., 2016). The amount of trade for Salvia species difficult to find. They are mostly collected from nature and sometimes being true to a species name is not possible. In 2019 ca 2400 tonnes of S. officinalis were exported from Turkey while ca 500 tonnes of S. fruticosa were exported (TUIK, 2020). S. aramiensis only collected 
from the flora of Hatay and consume in the local area, there are no records for this species trade. Salvia fruticosa Mill. (Syn: S. triloba) known as "Greek sage", "Anatolian sage" and "Dalmatian sage" is a culinary herb that used for its medicinal benefits. S. aramiensis Rech. fil., known as "Hatay sage" naturally grows in a particular region of Turkey and used as herbal tea and incense in the local area. Salvia aramiensis with low thujone and camphor levels in essential oil have a great potential to be a commodity of trade similar to $\mathrm{S}$. fruticosa (Demirci et al., 2002). In developing countries traditional medicine is still utilized while these drugs only used as alternative or complementary in industrialized countries (FAO, 2005). Developed countries such as Hong Kong, the USA, and Japan are the main markets for medicinal and aromatic plants (MAPs) while developing countries are the main exporters of MAPs.

Today there is very multicultural diversity for economically important plants in the sight of conservation of genetic diversity. The knowledge of genetic diversity conservation is highly improved for industrialized plants
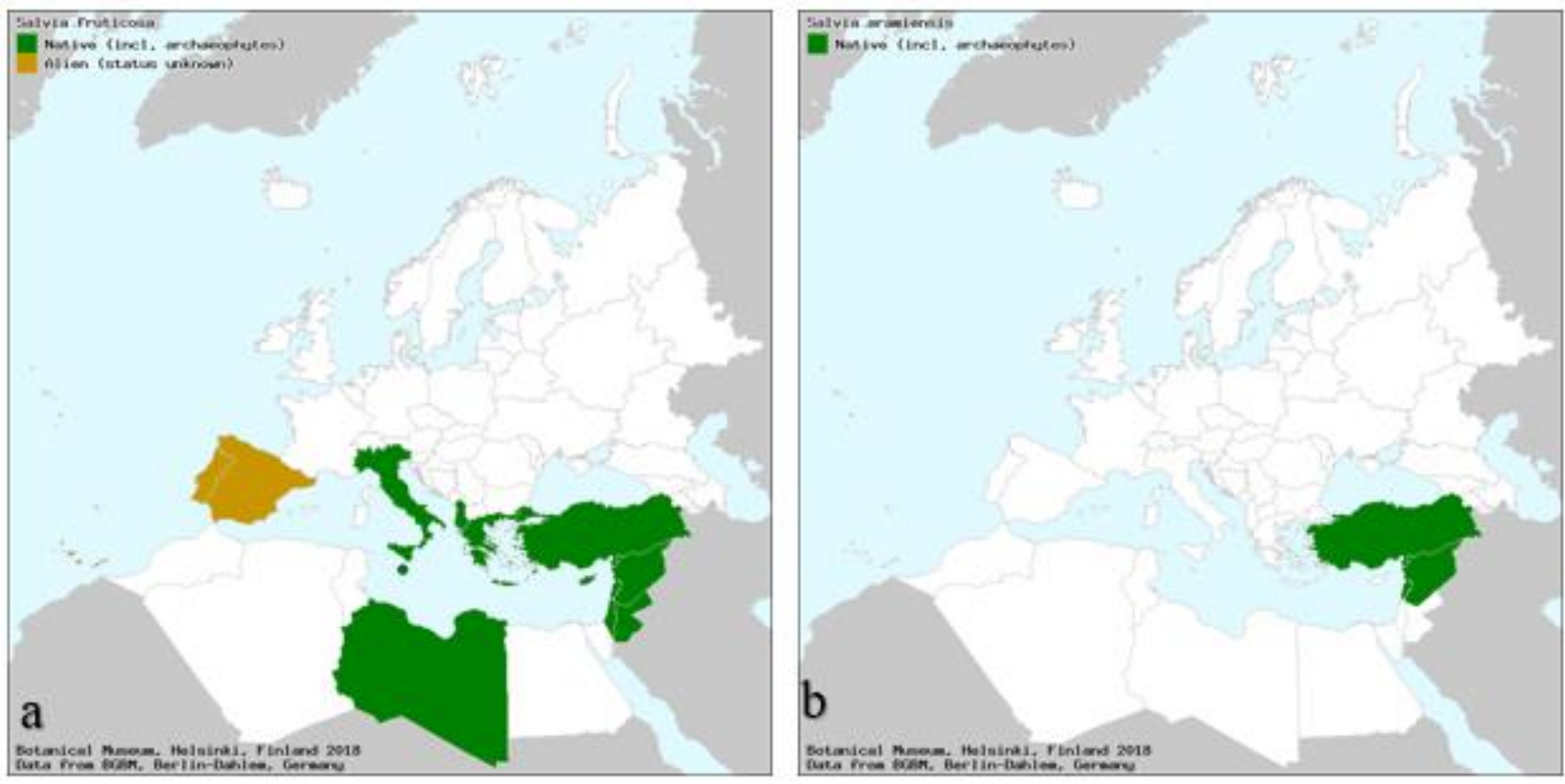

Figure 1. Distribution map of Salvia fruticosa (a-left) and S. aramiensis (b-right) (Anonymous, 2020) while these information is not sufficient for MAPs. The main problem for conservating of MAPs are a leak of knowledge on population size and structure, origin, traded quantities and commodities, domestication and conservation.

In most industrialized countries, MAPs are collected from wild however with an increasing demand the collection becoming more and more problem. Many species are similar for the unconscious collectors and it is challenging to preserve these species without knowing the collection method and location (Lange, 2006). There are many organizations such as FAO, IPGRI, UPOV, ECP/GR, IUCN, WWF, EUROPAM and ISSCMAP which are working to preserve and maintain the diversity of medicinal and aromatic plants. These organizations bring together governmental and nongovernmental organizations and mostly work on in-situ conservation of endemic plants (Baydar and Telci, 2016). Because of active ingredients and new usage areas, medicinal and aromatic plants should be evaluated more carefully. 


\section{Botany and Distribution}

The genus Salvia with approximately 1000 species distributed in many different ecosystems (Walker et al., 2004). Salvia fruticosa Mill. and Salvia aramiensis Rech. fil. are both evergreen, perennial, semi-shrub aromatic plants. Salvia fruticosa native to Albania, Cyprus, East Aegean, Greece, Italy, Kriti, Lebanon-Syria, Libya, Palestine and Turkey (Hedge, 1982). S. fruticosa introduced into Algeria, Canary, Madeira, Morocco, Portugal and Spain (Figure 1-a). S. aramiensis Rech. fil. is native to Turkey, Lebanon and Syria (Davis, 1982), however, there were not

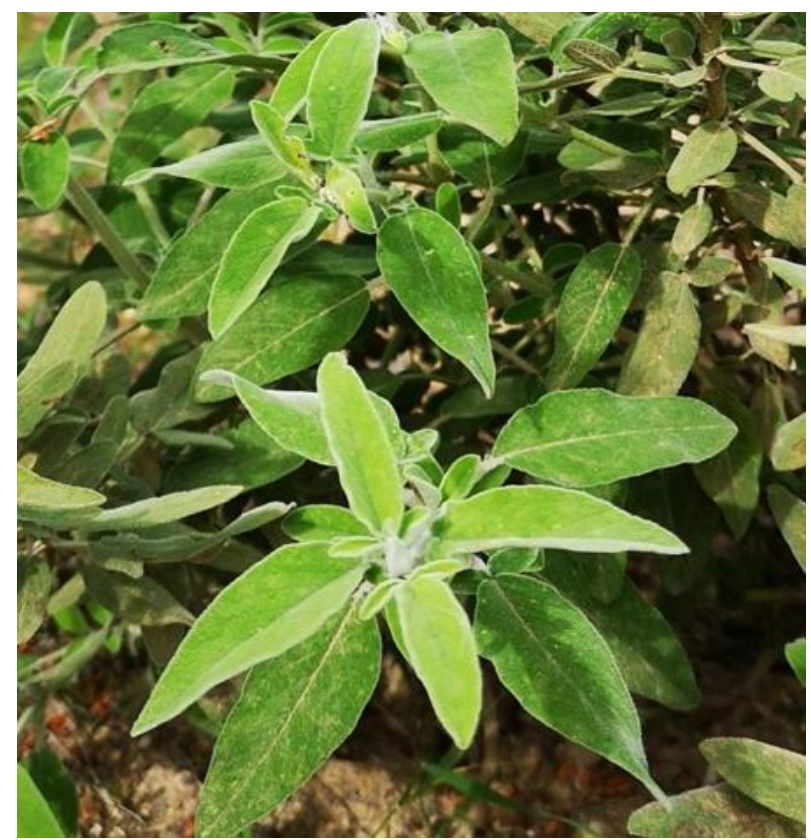

any publication found from Lebanon and Syria (Figure 1-b). In Turkey $S$. aramiensis Rech. fil. is widespread only in Amanos mountains, where mostly Hatay province is located (Saroglu, 2013). Amanos Mountains, which starts from north of the Mount Cassius to southwest-northeast direction reaches to Kahramanmaraş province, limits Amik Plain and the northwest side of Asi (Orontes) River (Aytac and Semenderoglu, 2014). S. aramiensis Rech. fil. and S. tomentosa Mill. grows sympatrically in many areas however hybrid plants were not detected from any studies (Davis, 1982).

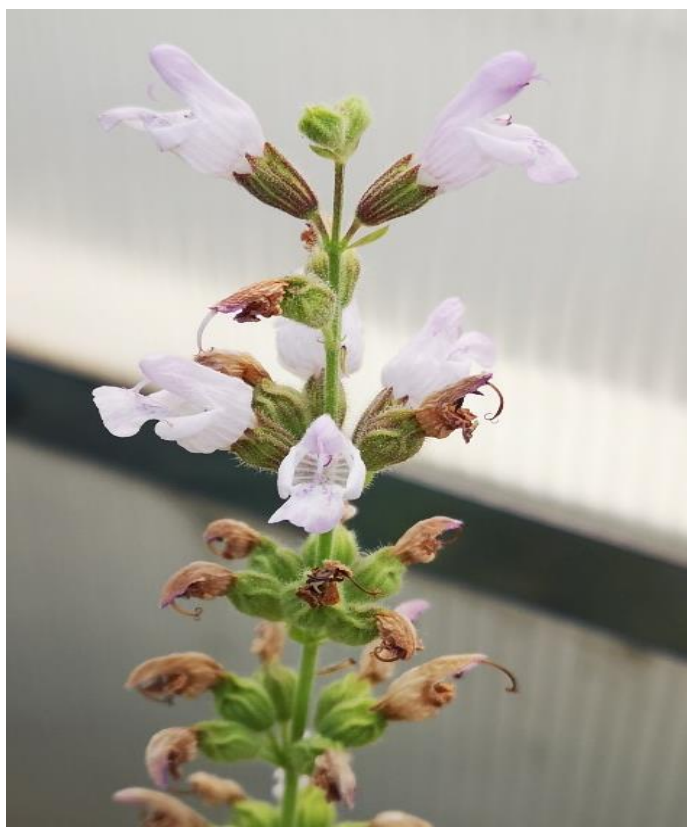

Figure 2. Leaf and flower view of Salvia fruticosa Mill.

Leaf and flower morphology of S. aramiensis Rech. fil. is very similar to $S$. aucheri var. aucheri Bent., however, essential oil components are very distinct (Kurkcuoglu et al., 2002). In addition, in $S$. aucheri var. aucheri Bent. trilobed leaf forms could be seen but in $S$. aramiensis Rech. fil. trilobed leaf could not form. Stems of $S$. fruticosa Mill. (Figure 2) are upright up to $1.6 \mathrm{~m}, S$. aramiensis Rech. fil. (Figure 3) plants shorter up to $1 \mathrm{~m}$. The feather cover in the trunk shows a lot of variation, sparse or dense below the body pubescent lanate or glandular, usually dense eglandular villous and short or long glandular-pubescent on the upper part of the trunk, sometimes glabrous in S. fruticosa Mill. while in S. aramiensis Rech. fil. dense eglandular-tomentose and stemless glandular hairs below the trunk, top at the part gently pilose or sub-glabrous. Leaves are simple in both species, in $S$. fruticosa also triple lobed could occur. S. fruticosa Mill. and $S$. aramiensis Rech. fil. are both entomophile and outcrossing species. S. fruticosa Mill. leaf 
color is yellow-green and S. aramiensis Rech. fil. leaf color is grey-green. Gall forms named "Elma (apple)" in colloquial. Gall formation could not occur in all the $S$. fruticosa populations such as Spain and Madeiran (Rivera et al., 1994). S. fruticosa Mill. petals pink, lilac to violet-blue, rarely white, in $S$. aramiensis Rech. fil. mauve to pink. Habitats of the $S$. fruticosa Mill. are maquis shrub land to frigana, rocky slopes in altitudes 1-1000 m

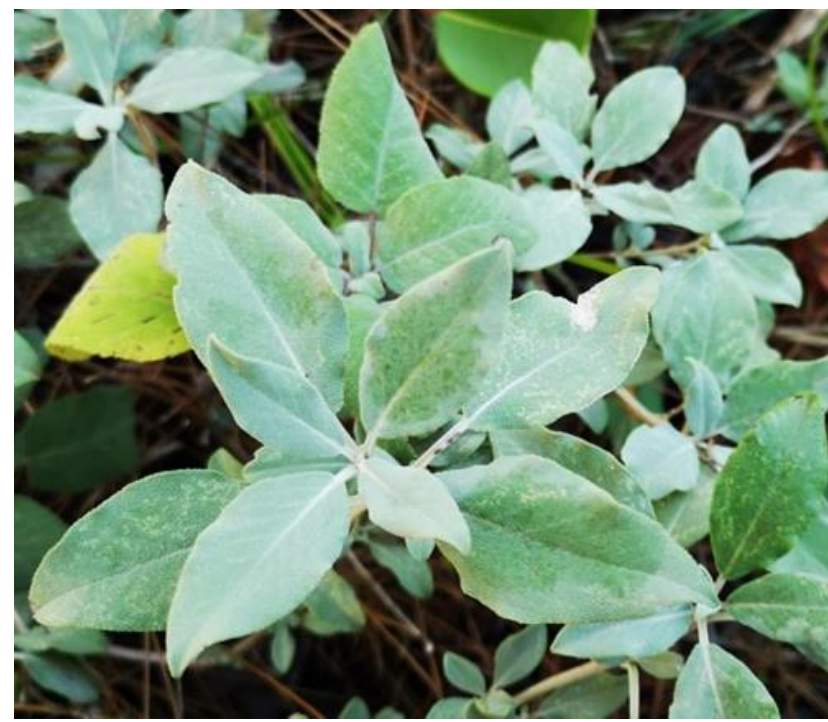

Figure 3. Leaf and flower view of Salvia aramiensis Rech. fil.

\section{Domestication, Spread and Cultivation}

S. fruticosa Mill. naturalized in Malta island, Spain, Portuguese and Croatia (Greuter et al., 1986; Radosavljevic et al., 2015). S. fruticosa Mill. is a culinary herb that cultivated in many different countries (Delamare et al., 2007). However, Salvia aramiensis Rech. fil., grows only in the Amanos Mountains and trading occurs only in close provinces (Davis, 1982; Karaman et al., 2007). In Greece dry herb of $S$. (Rivera et al., 1994). Besides, S. aramiensis Rech. fil. has a similar usage that dry herb of the plant burns in the house and believed to send away bad spirits. Thereat category of $S$. fruticosa Mill. is less concern (LC) at regional, national and international levels. Threat category of S. aramiensis Rech. fil. is as follows, for regional level vulnerable (VU), fruticosa Mill. burn in a house to cleanse it and in S. aramiensis Rech. fil. are red pine forest clearance and rocky slopes, altitudes 250-1000 m. Both of the species described as Mediterranean elements, to be specified $S$. fruticosa Mill. Mediterranean and $S$. aramiensis Rech. fil. East Mediterranean element. S. fruticosa Mill. and S. aramiensis placed in the same group in Flora of Turkey (Group E) (Dogan et al., 2008).

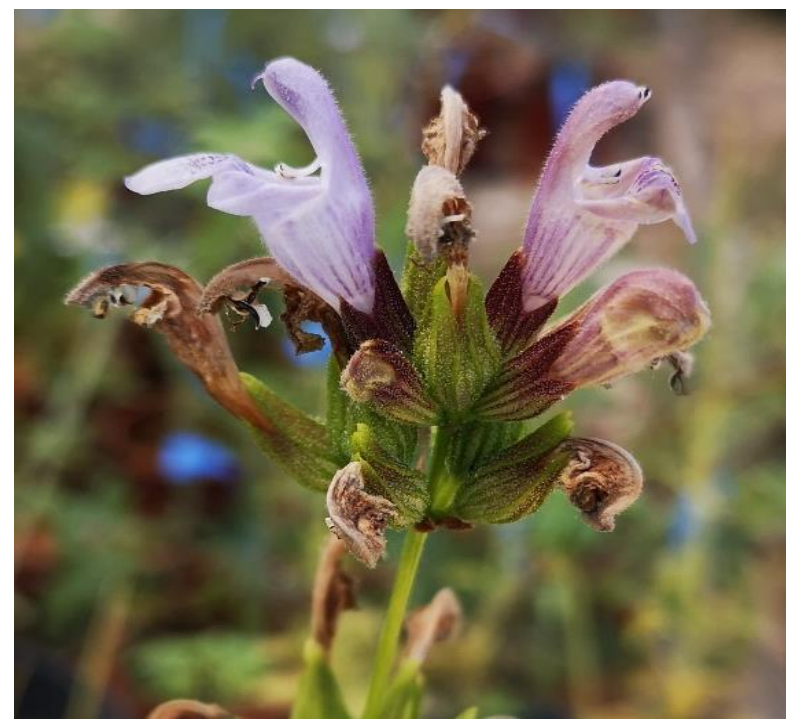

national-level vulnerable (VU) and international level less concern (LC) (IUCN Red List Criteria 2001 in Celep et al., 2010). The number of Salvia fruticosa Mill. individuals are unknown however, this species is widespread and abundant in parts of its range, but is under high collection pressure and may be declining.

Most of the $S$. fruticosa Mill. and all of the $S$. aramiensis Rech. fil. were collecting from wild populations. There are many steps until herbs become consumable, harvesters mostly uneducated people about species and collecting, intermediary buyer, exporter, international buyer and retailer that process the plants. The medicinal and aromatic plant industry needs high-quality material that also corrects in the name of the desired species. Sustainability of plant genetic 
resources become more and more important. These conditions necessitated the cultivation of medicinal plants (Dudai and Yaniv, 2014). The domestication of a wild plant into similar climatic conditions is an easier otherwise acclimatizing process necessary.

Domestication is a process characterized by the occurrence of key mutations in morphological, phenological, or utility genes, which leads to the increased adaptation and use of the plant; however, this process followed by modern plant breeding practices has presumably narrowed the genetic diversity (Chaudhary, 2013). In 1980s domestication and selection of $S$. fruticosa Mill. were studied in Israel, but researchers stated that any wide-scale cultivation of this crop today does not exist (Putievsky and Ravid, 1984; Dudai and Yaniv, 2014). Domestication and characterization of $S$. fruticosa Mill. and S. aramiensis Rech. fil. were studied in Hatay province, 2 genotypes of $S$. fruticosa Mill. and 3 different ecotypes of $S$. aramiensis were used. In that study highest dry herb yield found for $S$. fruticosa Mill. as $1252.74 \mathrm{~kg} / \mathrm{da}$ and $642.29 \mathrm{~kg} / \mathrm{da}$ for $S$. aramiensis Rech. fil. In the study essential oil range was also determined, S. fruticosa essential oil was ranged between 1.13$3.65 \%$, essential oil range of $S$. aramiensis was ranged between 1.13-3.06\% (Ayanoglu et al., 2012). More studies should carry out both of the sage species. Cultivation for commercial purposes is rare and seeds mostly collecting from the nearest wild population for cultivation. S. fruticosa Mill. and S. aramiensis Rech. fil. utilized for their secondary metabolites. Secondary metabolites show diversity even with monomorphic and same population through age. Karasou and Kokkini (1997), point out $S$. fruticosa Mill. leaf morphology varies in the different geographical areas of Greece. The northern part of the country where the transitional climate occurs; leaves were found flat and entire, while South of Greece where real Mediterranean climate occurs; total leaf surface were decreased gradually and threelobed, canaliculate-undulate forms appear (Karousou et. al, 2000). Murcian S. fruticosa Mill. populations differentiate within two main types of leaves ovate-lanceolate and ovate (Rivera et al., 1994). The higher light absorption on the leaf surface causes some morphological difference in S. fruticosa Mill. leaves; the number of small leaves and folding of leaf margins decreases while sparse and dense cover with hairs on the abaxial surface (Szwarcbaum, 1982).

\section{Genetic Resources: Essential oil yield and content, biological properties}

Considering both $S$. fruticosa Mill. and $S$. aramiensis Rech. fil. almost all the sources are wild. There are very limited number of varieties that developed by hybridization or selection of $S$. fruticosa Mill. In Southern Cyprus, Salvia fruticosa Mill. were recorded as a highly used shrub and some research was done to determine effective agricultural practices for cultivation in Agricultural Research Institute (Droushiotis and Della, 2002). Salvia fruticosa has been under protection in Israel National Parks and Reserve areas that collecting of plants are not permitted since 1956 (Putievsky, 2002). Crete is one of the most important genetic resources for $S$. fruticosa Mill. Evaluation of 37 different $S$. fruticosa populations from Crete resulted in geographic diversity occurs in the populations (Karousou and Kokkini, 1997). In the west of Crete $S$. fruticosa, branches are taller, leaves are big, dark green and the verticillasters of leaves are distinct, leaf blade flat and cornered. Through eastwards researchers found out that leaf forms were changed and in the east of island species with many small branches, dense leaf verticillasters, leaves are light green and small, leaf blade trilobed. Essential oils were also changed the highest essential oil content found in the east of the island with 3-4\%. Essential oil content and composition also vary in the wild resources. The essential oil 
content of 20 different S. fruticosa from native populations of Crete shows high diversity from 1.1 to $5.1 \%$. In the west of the Crete 1.8 cineole content lower than in the east of the island (Karousou et al. 1998). The aromatic diversity of Turkey resulted that native $S$. fruticosa plants belong to the group CiCa which 1.8 cineole is dominant followed by camphor (Baser, 2002). S. aramiensis essential oil content found from different studies between 1-3\% (Demirci et al., 2002; Karaman et al., 2007; Askun et al., 2010).

Many of the endemic and wild seeds of medicinal and aromatic plants have a germination problem (Abdollahi, 2012). $S$. fruticosa Mill. also have partial germination problem but with the addition of some priming applications germination in higher ranges are possible (Sonmez, 2019). However, the germination problem of $S$. aramiensis Rech. fil. seeds are still unsolved (Bahadirli and Ayanoglu, 2019). The other gaps about the genetic resources is that diseases that threatened the field collections especially Fusarium oxysporum and powdery mildew. In the study Salvia fruticosa plants were selected from natural flora of Turkey due to the high drog herb yield and essential oil content, however, during field experiments selected plants were died because of the Fusarium oxysporum infection (Bayram, 1999). Furthermore, S. fruticosa Mill. Found so susceptible to powdery mildew that causes early defoliation and senescence (Soylu et al., 2019). More detailed studies should be done to protect genetic resources and selected material from pest and diseases. There are many studies maintained in both of the species. Determining wild populations agronomic traits and essential oil (Karoussou and Kokkini, 1997; Karoussou et al., 1998; Bayram et al., 1999; Bayram, 2001; Demirci et al., 2002; Karaman et al., 2007; Mossi et al., 2011; Schmiderer et al., 2013; Cvetkovikj et al., 2015; Karik, 2015; Uysal, 2015; Sarrou et al., 2016; Kelen and Tepe, 2017; Zgheib et al.,
2019); cultivated populations agronomic and essential oil features (Karik and Saglam, 2017; Ayanoglu et al., 2017); antifungal, antioxidant, antimicrobial and antimycobacterial (Sivropoulou et al., 1997; Sokovic et al., 2002; Askun et al., 2010; Giweli et al., 2013; Topcu et al., 2013; Sarrou et al., 2016; Ertas et al., 2017; Karik and Saglam, 2018); anti-alzheimer (Alim et al., 2018); optimal harvesting time from wild populations (Gul et al., 2002); hybridization in wild population (Radosavljevic et al., 2019); artificial hybridization (Putievsky et al., 1990; Bahadirli and Ayanoglu, 2019); genetic diversity with molecular markers (Skoula et al. 1999; Bahadirli et al., 2017). Universal molecular and morphologic diversity of $S$. fruticosa, pests and diseases, resistance to abiotic stress factors, different aspects of medicinal properties of both species exceedingly essential and requires more study.

Biological properties of Salvia fruticosa Mill. have been studied a lot compared to the $\mathrm{S}$. aramiensis. An appropriate reason for this is the widespread distribution of $S$. fruticosa Mill. The main focus on both of the species was essential oil yield and composition (Schmiderer et al., 2013; Sarrou et al., 2016). On the other hand, ISO 9909:1997 report limits only the chemical composition of $S$. officinalis L. essential oil. In this report essential oil composition of $S$. officinalis L. should contain $\alpha$-thujone (18.0-43.0\%), camphor (4.5-24.5\%), 1.8 cineole (5.5$13.0 \%), \beta$-thujone $(3.0-8.5 \%), \alpha$-humulene $(\leq 12.0 \%), \alpha$-pinene $(1.0-6.5 \%)$, camphene $(1.5-7.0 \%)$, limonene (0.5-3.0\%), bornyl acetate $(\leq 2.5 \%)$, linalool and bornyl acetate $(\leq 1.0 \%)$. The main concern of $S$. officinalis L. was about thujone content of the essential oil, however according to EMA (European Medicines Agency, 2016) exposure of 3 and 7 mg/day should not take special concerns. There is a wide variation on $S$. fruticosa essential oil composition. The major compounds mostly found as 1.8 cineoele and 
camphor, however their rates are variable (Gul et al., 2002; . Cvetkovikj et al., 2015; Kavoura et al., 2019; Zgheib et al., 2019). S. fruticosa Mill. is an important commodity as S. officinalis L. within this view S. fruticosa essential oil also needs ISO standard limits.

S. aramiensis essential oil have been studied in a few researches. In the study where an antioxidant and antimicrobial profile of $S$. aramiensis compared with $S$. aucheri var. aucheri and $S$. pilifera, antioxidant and antimicrobial activity of $S$. aramiensis found stronger than the other studied species (Kelen and Tepe, 2017). In the same study, major compounds of $S$. aramiensis essential oil were found as follows 1.8 cineole (46.0\%), $\beta$-pinene $(10.3 \%)$ and camphor $(8.7 \%)$. The anti-Alzheimer activity of $S$. aramiensis Rech fil. root extracts were studied and the highest inhibitory activity was obtained with dichloromethane extract followed by methanol extract (Alim et al., 2018). S. fruticosa Mil. and $S$. aramiensis Rech fil. extracts did not show antimycobacterial activity (Askun et al., 2010). Studies reveal that the essential oil content of $S$. aramiensis Rech. fil. is lower compared to the $S$. fruticosa Mill. (Demirci et al., 2002; Karaman et al., 2007). The essential oil composition of these species shows similarity yet thujone and camphor range is much lower in $S$. aramiensis Rech. fil. (Bahadirli and Ayanoglu, 2019). Karaman et al. (2007) found that major compounds of $S$. aramiensis were 1,8-sineol $(\% 60.0), \beta$-pinene (\%9.0), myrcene (\%3.70), $\alpha$-pinene $(\% 3.40)$ and germacrene-D (\%2.90). There are many mechanisms that affect secondary metabolites of Salvia fruticosa Mill. altitude is one of them. The effect of different altitudes $(0-200 \mathrm{~m} ; 300$ $500 \mathrm{~m} ; 600-800 \mathrm{~m}$ ) on $S$. fruticosa Mill. essential oil yields and components were evaluated. Essential oil yield found highest in $300-500 \mathrm{~m}$ as $5.1 \%$ while 1.8 cineole found highest in the same altitude. Different altitudes (Kaplan and Kocabas Oguz, 2013).

\section{Molecular characterization}

Molecular methods have been used widely for discrimination of medicinal and aromatic plants. International studies that have samples from different countries put more general perspective while national studies observed only in limited areas. Molecular markers such as RAPD, AFLP, SSR, SNP are the main methods used for identifying wild or cultivated resources. However, most of the molecular studies associate morphological characters or locations, not secondary metabolites. The main reason for that is the variability of secondary metabolites. On the other hand, it is essential to combine both methods to describe genetic resources clearly. The advantages of molecular characterization that markers are very sensitive to any genetic differentiation and also variation could detect in the early phase of the plant growth. The disadvantages of molecular characterization are the expenses and technological requirements are not developed enough in many underdeveloped countries. Considering both sides molecular characterization is open to progress and if utilizing with breeding programs could be more possible, more and accelerate progress could obtain. Some studies revealed genetic diversity of $S$. fruticosa in the natural populations (Karaca et al., 2008; Radosavljević et al., 2011; Bahadirli, 2014; Radosavljević et al., 2015). In the study from Radosavljevic et al. (2015) hybridization between $S$. fruticosa and S. officinalis was detected. Skoula et al. (1999), studied genetic and essential oil profile of $S$. fruticosa in three different populations in Crete. Molecular markers (RAPD) discriminate populations in to three different group but two populations find closer, similar results were obtain also when the essential oil profile was analyzed. These results showed the importance of genetic background. Secondary metabolism pathways particularly in essential oil biosynthesis are necessary for to maintain biotechnological production in a large scale. 
Chatzopoulou et al. (2010) analysed selected genes that involved in the secondary metabolite synthesis in tricomes of $S$. fruticosa with cDNA library. The results of the study indicate a series of novel genes associated with secondary metabolism.

\section{Varieties and Breeding}

In Turkey only one variety of Salvia fruticosa 'Karik'were patented. The other record was the hybrid variety 'Newe Ya'ar 4' from Israel. Alternative strategies to enhance the dissemination of varieties among researchers and farmers are crucial for the improvement and conservation of genetic resources.

Salvia fruticosa and Salvia aramiensis species both have been utilized as herbal tea, fragrance in pharmaceutical industry and food additives, furthermore, their essential oil constituents show antioxidant, anticancer, anti-alzheimer, antimicrobial activity. Major constraints are their essential oil and biological activity. In many of biological activity research the origin of plant is unknown, in addition, agricultural studies and conservation is disregarded. Secondary metabolites of the species are unstable, correlation between their active ingredient and biological properties are crucial.

High herb yield with active ingredient, resistant to biotic and abiotic stress factors and absence of unwanted compounds with highly desired compounds mostly are the main purposes for breeding. Survey of the natural population, characterization of the resource, selection (individual or mass), propagation of the material with vegetative or generative parts, selection, cultivation and selection for desired traits until obtaining desired traits. First artificial hybridization was done between $S$. fruticosa and $S$. officinalis by Putievsky et al. (1990) to obtain the highest adaptability to flora with high yield. The hybridization range was between
S. officinalis $\times$ S. fruticosa $36 \%$ and $S$. fruticosa $\times$ S. officinalis $34 \%$. Hybrids essential oils were found in the middle of parent species. Thujone content of hybrids was similar to $S$. officinalis, however, 1.8 cineole and camphor ranges were between middle of the parent species (Putievsky et al., 1990). One variety named Neve Ya'ar No:4 was developed from this hybridization study (Dudai et al., 1999). Another hybridization study was done between $S$. aramiensis and $S$. fruticosa, hybridization range between $S$. aramiensis $\times$ S. fruticosa found as $25.68 \%$ and $S$. fruticosa $\times$ $S$. aramiensis as $44.29 \%$. Essential oil range between $S$. aramiensis $\times S$. fruticosa $0.75-$ $3.97 \%$, S. fruticosa $\times S$. aramiensis $1.04-$ $3.84 \%$. In the same study hybrid plants with less than $1 \%$ thujone content with higher than $60 \%$ were observed between both species (Bahadirli and Ayanoglu, 2019). Spontaneous hybrids between cultivated $S$. fruticosa and $S$. officinalis were also studied considering essential oil content and components. In the study, essential oil contents and components of the hybrids were found in the middle of the parent plants close to the $S$. officinalis parent (Karik and Saglam, 2018). Natural hybrids of $S$. fruticosa and $S$. tomentosa were propagated with cuttings and agronomic features were evaluated. In the study, essential oil contents of hybrid plants were found mostly in the middle of the parent plants however some hybrid plants essential oils were found higher than the parent plants (Evropi-Sofia, 2013). Natural hybrid plants between $S$. fruticosa and $S$. officinalis species in Croatia and Spain, in both of these study only genetic characterization, were studied (Radosavljevic et al., 2019; Rivera et al., 2019).

From the study in Hatay region artificial hybridization between $S$. fruticosa and $S$. aramiensis were done with cultivated clones from natural populations. The main purpose of that study was to obtain new plants that contain high essential oil and 1.8 cineole with 
low thujone and camphor contents (Bahadirli and Ayanoglu, 2019). In other research from Israel, the study was done due to the demands of market. New variety were obtained between non-native $S$. officinalis and native $S$. fruticosa by hybridization and selection of superior genotypes. In the study the aim was, a plant with resembling $S$. officinalis in morphology and flavor additionally adaptive to intensive Israeli agricultural conditions (Dudai et al., 1999).

\section{Conclusion}

opens for essential oils in medicinal studies however reachable sources for public usage crucial. Biotechnological methods have very significant role in conservation, characterization and breeding of genetic resources, so their usage in the studies should increase. Furthermore functional genomic researches should be initiated to determine biotic and abiotic problems.

\section{Conflict of Interest}

The authors declare that they have no conflict of interest.

\section{References}

1. Abdollahi, J., Ebrahimi, M., Ramshini, H.A., Jaafari, A.A., Eftekhari, M., Mansouri, Y.S., Goharrizi, M.A.S.B., 2012. Seed germination as the majör conservation issue of endemic Iranian Salvia species. Journal of Medicinal Plants Research 6(1): 37-46

2. Alim, G.O., Yilmaz Ozden, T., Yazici Tutunis, S., Tan, N., Miski, M., 2018. Anti-alzheimer activity of Salviaaramiensis root extract. 12th International Symposium of Pharmaceutical Sciences (ISOPS12) Ankara, Turkey 26-29 June 2018, p 160-161

3. Anonymous, 2020. The Euro+Med PlantBase: the information resource for Euro-Mediterranean plant diversity. http://euromed.luomus.fi/euromed_map.php?ta xon=491871\&size=medium. 20/05/2020

4. Askun, T., Baser, K.H.C., Tumen, G., Kurkcuoglu, M., 2010. Characterization of essential oils of some Salvia L. species and their antimycobacterial activities. Turkish Journal of Biology, 34: 89-95

5. Ayanoglu, F., Kaya, D.A., Mert, A., Uygur, V., 2012. Hatay yöresinde doğal olarak yetişen adaçayı
Conservation and characterization of $S$. aramiensis genetic resources are necessary in the first place. Increasing demand on $S$. fruticosa requires new varieties that adaptive to agrological conditions, with stable yield and diseases resistant. Therefore, it is very important to share and exchange present genetic resources. $S$. aramiensis merit more national and international recognition. Cultivation has become a key factor in sustainable flora, time and cost saving through transfer. New area of utilization

(Salvia sp.) türlerinin kültüre alınması, verim ve kalite özelliklerinin belirlenmesi. TÜBİTAK TOVAG, Project No: 1900161, $152 \mathrm{p}$

6. Ayanoglu, F., Kaya, D.A., Bahadirli, N.P., Turkmen, M., 2017. Variations of essential oil contents and components of 16 wild Salvia species and propagated clones. Natural Volatiles and Essential Oils 4(3): 63

7. Aytac, A.S., Semenderoglu, A., 2014. Climatic characteristics at the central uplands and surrounding areas in the Amanus Mountains. Journal of Turkish Studies 9(2): 251-289

8. Bahadirli, N.P., 2014. SSR marker-based molecular characterization and cytogenetic analysis of wild sage (Salvia spp.) populations native to Hatay province. Hatay Mustafa Kemal University, Department of Field Crops, Master thesisp 99

9. Bahadirli, N.P., Ayanoglu, F., Yuksel, C., Ergul, A., 2017. Molecular characterization of some Sage species (Salvia spp.) with microsatellite markers in flora of Hatay, Turkey. Natural Volatiles and Essential Oils 4(2): 18

10. Bahadirli, N.P., Ayanoglu, F., 2019. Preliminary results: Assessment of new Salvia chemotypes for herbal tea industry by hybridization. Scientific Papers. Series A. Agronomy 62(1): 501-506

11. Baser, K.H.C., 2002. Aromatic biodiversity among the flowering plant taxa of Turkey. Pure Applying Chemistry 74(4): 527-545.

12. Baydar, H., Telci, I., 2016. Tibbi ve aromatik bitkilerde ıslah, tohumluk, tescil ve sertifikasyon. TURKTOB 12-16

13. Bayram, E., Ceylan, A., Geren, H., 1999. Anadolu Adaçayı (Salvia fruticosa Mill.) ıslahında geliştirilen klonların agronomik ve kalite özellikleri üzerinde araştırma. Türkiye 3. Tarla Bitkileri Kongresi, p 212-217 Kasım 1999 Adana.

14. Bayram, E., 2001. Batı Anadolu florasında yetişen Anadolu adaçayı (Salvia fruticosa Mill.)'nda uygun tiplerin seleksiyonu üzerinde araștırma. Turkish 
Journal of Agriculture and Forestry 25(6): 351357

15. Carović-Stanko, K., Petek, M., Grdiša, M., Pintar, J., Bedeković, D., Ćustić, M.H., Satovic, Z., 2016. Medicinal plants of the family Lamiaceae as functional foods - a review. Czech J. Food Sci., 34: 377-390.

16. Celep, F., Doğan, M., Kahraman, A., 2010. Reevaluated conservation status of Salvia L. (sage) in Turkey I: The Mediterranean and the Aegean geographic regions. Turk J Bot 34: 201-214

17. Chatzopoulou, F.M., Makris, A.M., Argiriou, A., Degenhardt, J., Kanellis, A.K., 2010. EST analysis and annotation of transcripts derived from a trichome-specific cDNA library from Salvia fruticosa. Plant Cell Rep. 29(5):523-34. doi: 10.1007/s00299-010-0841-9

18. Chaudhary, B., 2013. Plant domestication and resistance to herbivory. International Journal of Plant Genomics 1-14. http://dx.doi.org/10.1155/2013/572784

19. Cvetkovikj, I., Stefkov, G., Karapandzova, M., Kulevanova, 2015(a). Essential oil composition of Salvia fruticosa Mill. populations from Balkan Peninsula. Macedonian Pharmaceutical Bulletin, 61(1): 19-26.

20. Davis, P.H., 1982. Flora of Turkey and The East Aegeans Islands (Vol: 1-11). The Edinburg University Press. ISBN: 9780852243961,England.

21. Delamare, A., Pistorello, I., Artico, L., Serafini, L., Echeverrigaray, S., 2007. Antibacterial activity of essential oils of Salvia officinalis L. and Salvia triloba L. cultivated in South Brazil. Food Chem. 100(2): 603-608

22. Demirci, B., Başer, K.H.C., Tümen, G., 2002. Composition of the essential oil of Salvia aramiensis Rech. Fil. growing in Turkey. Journal of Flavour and Fragrance 17: 23-25.

23. Droushiotis, D., Della, A., 2002. Genetic resources of medicinal and aromatic plants in Cyprus with emphasis on the selection, evaluation and management of Origanum dubium. In: Report of a working group on medicinal and aromatic plants, p 39-41

24. Doğan, M., Pehlivan, S., Akaydın, G., Bağcl, E., Uysal, İ., Doğan, H.M., 2008. Türkiye'de Yayılıș Gösteren Salvia L. (Labiatae) Cinsinin Taxonomik Revizyonu. Tübitak Proje No: 104 T 450.

25. Dudai, N., Lewinsohn, E., Larkov, O., Katzir, I., Ravid, U., Chaimovitsh, D., Sa'adi, D., Putievsky, E., 1999. Dynamics of Yield Components and Essential Oil Production in a Commercial Hybrid Sage (Salvia officinalis L. $\times$ Salvia fruticosa ev.) Neve Ya'ar No:4. Journal Agriculture Food Chemistry, 47: 4341-4345.

26. Dudai, N., Yaniv, Z., 2014. Endemic aromatic medicinal plants in the Holy Land vicinity. In:
Yaniv Z, Dudai N (ed) Medicinal and aromatic plants of the Middle-East, Springer , London New York, p 37-58

27. EMA (European Medicines Agency), 2016. European Union herbal monograph on Salvia officinalis L.,folium. In: Committe on Herbal Medicinal Products. Available via EMA. https://www.ema.europa.eu/en/documents/her bal-monograph/final-european-union-herbalmonograph-salvia-officinalis-l-folium-revision1_en.pdf. Accessed 4 Nov 2019

28. Ertas, A., Alkan, H., Akdeniz, M., Sahin, H., Alacabey, I., Odabasi, M., Acet, O., Kolak, U., 2017. The antioxidant activity and chemical composition of essential oils of Salvia aramiensis and Calamintha nepeta The 3rd International Symposium on EuroAsian Biodiversity 05-08 July 2017, Minsk Belarus, p 612

29. Evropi-Sofia, D., 2013. Cultivation of plants of the genus Salvia. Aristotle University Thessaloniki, Department of Biology Master Thesis, p 98

30. Exarchou, V., Kanetis, L., Charalambous, Z., Apers, S., Pieters, L., Gekas, V., Goulas, V., 2015. HPLCSPE-NMR characterization of major metabolites in Salvia fruticosa Mill. extract with antifungal potential: relevance of carnosic acid, carnosol, and hispidulin. J Agric Food Chem. 63(2):457-63. doi: 10.1021/jf5050734

31. FAO, 2005. Trade in medicinal plants. Raw Materials, Tropical and Horticultural Products Service Commodities and Trade Division Economic and Social Department Food and Agriculture Organization of the United Nations Rome. http://www.fao.org/3/af285e/af285e00.pdf

32. Giweli, A.A., Dzamic, A.M., Sokovic, M., Janackovic, M.S.R.P., Marin, P.D., 2013. The chemical composition, antimicrobial and antioxidant actiıvities of the essential oil of Salvia fruticosa growing wild in Libya. Arch. Biol. Sci. Belgrade, 65(1): 321-329

33. Greuter, W., Burdet, H.M., Long, G., (eds.), 1986. Med-Cheklist: A critical inventory of vascular plants of the circum-mediterranean countries Conservatoire et Jardin botaniques, Ceneve

34. Gul, G.S., Cevik, İ., Gul, M., Ozel, N., 2002. Determination of harvesting time of oregano (Origanum onites) and sage (Salvia triloba) using essential oil analysis in different zones of Aegean Region Ege Forestry Research Institute, Technical Bulletin, 153(28): $21 \mathrm{p}$

35. Hedge, I.C., 1982. Salvia L. In P. H. Davis (ed.) Flora of Turkey and the East Agean Islands. Edinburg University Press, Vol:7, p 400-461

36. Karaca, M., Ince, A.G., Tugrul Ay, S., Turgut, K., Onus, A.N., 2008. PCR-RFLP and DAMD-PCR genotyping for Salvia species. Journal of the 
Science of Food and Agriculture 88(14): 25082516

37. Kaplan, M., Kocabaş Oğuz, I., 2013. Doğadan toplanan adaçayı (Salvia fruticosa Mill.) bitkisinin uçucu yağ bileșenleri ve bitki besin maddeleri üzerine rakımın ve yetiștiği toprak özelliklerinin birlikte etkisinin değerlendirilmesi. TÜBİTAK TOVAG, Project No: 1120212, p 57

38. Karaman, Ş., İlçim, A., Çömlekçioğlu, N., 2007. Composition of the essential oils of Salvia aramiensis Rech. Fil. and Salvia cyanescens BOISS. \& BAL.. Pak. J. Bot. 39(1): 169-172

39. Karlk, Ü., 2015. Some yield and quality characteristics of Anatolian Sage (Salvia fruticosa Mill.) populations in Aegean and West Mediterranean Region. Journal of Tekirdag Agricultural Faculty 12(2): 32-42.

40. Karık, Ü., Sağlam, A.C., 2017. Tekirdağ ekolojik koşullarında Anadolu Adaçayı (Salvia fruticosa Mill.) popülasyonlarının verim ve kalite özelliklerinin belirlenmesi. Tarla Bitkileri Merkez Araştırma Enstitüsü Dergisi 26(2): 203-215

41. Karık, Ü., Sağlam, A.C., 2018. Marmara Bölgesi'ndeki Anadolu Adaçayı (Salvia fruticosa Mill.) populasyonlarının uçucu yağ bileşenleri, toplam antioksidan aktivite, toplam fenolik ve flavonoid madde miktarlarının belirlenmesi. ANADOLU J. of AARI 28(2): 37-47

42. Karousou, R., Hanlidou, E., Kokkini, S., 2000. The sage plants of Greece: Distribution and infraspecific variation. In: Kintzios SP (ed) Sage the genus Salvia, Taylor and Francis, Netherlands, p27-46

43. Karoussou, R., Kokkini, S., 1997. Distrubition and clinal varitian of Salvia fruticosa Mill. (Labiateae) on the Island of Crete. Willdenowia, 27: 113-117

44. Karoussou, R., Vokou, D., Kokkini, S., 1998. Variation of Salvia fruticosa essential oils on the Island of Crete (Greece). Bot. Acta., 111: 250-254.

45. Kavoura, D., Kyriakopoulou, K., Papaefstathiou, G., Spanidi, E., Gardikis, K., Louli, V., Aligiannis, N., Krokida, M., Magoulas, K., 2019. Supercritical CO2 extraction of Salvia fruticosa. The Journal of Supercritical Fluids, 146: 159-164.

46. Kelen, M., Tepe, B., 2007. Chemical composition, antioxidant and antimicrobial properties of the essential oils of three Salvia species from Turkish flora. Bioresour Technol 99(10): 4096-104

47. Kintzios, S.E., 2000. Sage: The genus Salvia. Taylor and Francis, Netherlands, ISBN 9789058230058

48. Kurkcuoglu, M., Baser, K.H.C., Duman, H., 2002. Composition of essential oils from two varieties of Salvia aucheri Bentham growing in Turkey. Journal of Essential Oil Research 14: 241-242

49. Kusaksiz, G., (2019). Rare and endemic taxa of Lamiaceae in Turkey and their threat categories. Journal of Scientific Perspectives, 3(1): 69-84.
50. Lange, D., 2006. International trade in medicinal and aromatic plants. In: Bogers RJ, Craker LE, Lange D (eds) Medicinal and aromatic plants. Springer, Netherlands, p 155-170

51. Mossi, A.J., Cansian, R.L., Paroul, N., Toniazzo, G., Oliveira, J.V., Pierozan, M.K., Pauletti, G., Rota, L., Santos, A.C., Serafini, L.A., 2011. Morphological characterisation and agronomical parameters of different species of Salvia L. sp. (Lamiaceae). Brazilian Journal of Biology 71(1): 121-129

52. Pavlidou, V., Karpouhtsis, I., Franzios, G., Zambetaki, A., Scouras, Z., Mavragani Tsipidou, P., 2004. Insecticidal and genotoxic effects of essential oils of Greek sage, Salvia fruticosa, and Mint, Mentha pulegium, on Drosophila melanogaster and Bactrocera oleae (Diptera: Tephritidae) J Agric Urban Entomol 21(1):39-49

53. Putievsky, E., Ravid, U., 1984. Selection and cultivation of Salvia fruticosa from wild population in Israel. In: Genetiğc resources of aromatic and medicinal plants, Organized by EUCARPIA, FAO, Oeiras, Portugal, p 87-94

54. Putievsky, E., Ravid, U., Diwan-Rinzler, N., Zohary, D., 1990. Genetic affinities and essential oil composition of Salvia offcinalis L., S. fruticosa Mill., S. tomentosa Mill. and their hybrids. Flavour and Fragrance Journal 5:121-123

55. Putievsky, E., 2002. Medicinal and aromatic plants in the Israeli Gene Bank (IGB). In: Baričevič, D., J. Bernáth, L. Maggioni and E. Lipman (ed) Report of a Working Group on Medicinal and Aromatic Plants, Gozd Martuljek, Slovenia, p 57-69

56. Radosavljević, I., Jakse, J., Javornik, B., Satovic, Z., Liber, Z., 2011. New microsatellite markers for Salvia officinalis (Lamiaceae) and crossamplification in closely related species. American Journal of Botany 316-318.

57. Radosavljević, I., Satovic, Z., Satovic, Z., 2015. Causes and consequences of contrasting genetic structure in sympatrically growing and closely related species. AOB Plants 7: pvl106. doi:10.1093/aobpla/plv106

58. Radosavljević, I., Bogdanović, S., Celep, F., Filipović, M., Satovic, Z., Surina, B., Liber, Z., 2019. Morphological, genetic and epigenetic aspects of homoploid hybridization between Salvia officinalis L. and Salvia fruticosa Mill. Scientific Reports 9(3276): 2045-2322.

59. Rivera, D., Obon, C., Cano, F., 1994. The Botany, History And Traditional Uses Of Three-Lobed Sage (Salvia fruticosa Miller) (Labiatae). Economic Botany, 48(2): 190-195.

60. Saroglu, G., 2013. Amanos and Kasion Mountains in ancient literature. Mehmet Akif Ersoy Üniveristesi Sosyal Bilimler Enstitüsü Dergisi 5(9): 59-69 
61. Sarrou, E., Martens, S., Chatzopoulou, P., 2016. Metabolite profiling and antioxidant activity of sage (Salvia fruticosa Mill.) under the influence of genotype and harvesting period. Ind Crops Prod 94: 240-250.

62. Schmiderer, C., Torres-Londono, P., Novak, J., 2013. Proof of geographical origin of Albanian sage by essential oil analysis. Biochemical Systematics and Ecology 51:70-7

63. Senel, F.S., Orhan, I., Celep, F., Kahraman, A., Doğan, M., Yilmaz, G., Şener, B., 2010. Survey of 55 Turkish Salvia taxa for their acetylcholinesterase inhibitory and antioxidant activities. Food Chemistry 12(2010): 34-43

64. Skoula, M., Hilali, I.E., Makris, A.M., 1999. Evaluation of the genetic diversity of Salvia fruticosa Mill. clones using RAPD markers adn comparison with the essential oil profiles. Biochemical Systematics and Ecology 27(6): 559568

65. Sivropoulou, A., Nikolaou, C., Papanikolaou, E., Kokkini, S., Lanaras, T., Arsenakis, M., 1997. Antimicrobial, cytoto $\times$ ic and antiviral activities of Salvia fruticosa essential oil. American Chemical Society, 45(8): 3197-3201

66. Sokovic, M., Tzakou, O., Pitarokili, D., Couladis, M., 2002. Antifungal activities of selected aromatic plants growing wild in Greece. Nahrung 46(5): 317-320

67. Sonmez, C., Gokcol, A., Simsek Soysal, A.Ö., Bayram, E., Çelen, A.E., 2019. Research on germination and emergence performance enhancing treatments on sage (Salvia spp.) species. Turkish Journal of Agriculture-Food Science and Technology 7(3): 504-510

68. Soylu, S., Soylu, E.M., Kara, M., Kurt, Ș., Uysal, A., Hong, S.H., Shin, H.D., 2019. First report of powdery mildew caused by Golovinomyces neosalviae on Salvia fruticosa in Turkey. Plant Disease 103(11): 2950

69. Szwarchbaum, I., 1982. Influence of leaf morphology and optical properties on leaf temperature and survival in three Mediterranean shrubs. Plant science letters 26: 47-56

70. Topçu, G., Öztürk, M., Kuşman, T., Barla Demirkoz, A.A., Kolak, U., Ulubelen, A., 2013. Terpenoids, essential oil composition, fatty acid profile, and biological activities of Anatolian Salvia fruticosa Mill. Turkish Journal of Chemistry 37: 619-632

71. TUIK, 2020. Foreign trade statistics. https://biruni.tuik.gov.tr/disticaretapp/disticare t.zul?param $1=25 \&$ param $2=0 \&$ sitcrev $=0$ \&isicrev $=$ $0 \&$ sayac $=5802$. Last enter: $20 / 05 / 2020$

72. Uysal, F., 2015. Antalya florasında bulunan Anadolu adaçayı (Salvia fruticosa Mill.) populasyonlarında seleksiyon ıslahı ile üstün özelliklere sahip genotiplerin belirlenmesi.
Akdeniz Üniversitesi, Fen Bilimleri Enstitüsü, Tarla Bitkileri Anabilim Dalı p 104

73. Walker, J.B., Sytsma, K.J., Treutlein, J., Wink, M., 2004. Salvia (Lamiaceae) is not monophyletic: implications fort he systematics, radiation, and ecological specializations of Salvia and tribe Mentheae. Am J Bot 91(7): 1115-1125

74. Zgheib, R., Yassine, C., Azzi-Achkhouty Beyrouth, M.E., 2019. Investigation of essential oil chemical polymorphism of Salvia fruticosa naturally growing in Lebanon. Journal of Essential Oil Bearing Plants 22(2): 408-430. 